\title{
PENERAPAN METODE SIMPLE MULTI ATTRIBUTE RATING TECHNIQUE UNTUK PENENTUAN PENERIMA KREDIT KOPERASI
}

\author{
Ghana Widya Afani ${ }^{1}$, Karina Auliasari ${ }^{2}$, Renaldi Primaswara Prasetya ${ }^{3}$ \\ Program Studi Teknik Informatika S1, Fakultas Teknologi Industri \\ Institut Teknologi Nasional Malang, Jalan Raya Karanglo km 2 Malang, Indonesia \\ 1618007@scholar.itn.ac.id
}

\begin{abstract}
ABSTRAK
Koperasi adalah badan usaha yang beranggotakan perseorangan atau badan hukum koperasi yang melandaskan kegiatannya berdasarkan prinsip koperasi sekaligus sebagai gerakan ekonomi rakyat yang berdasarkan asas kekeluargaan. Dalam hal penentuan kredit di Koperasi, proses penyeleksian kriteria dalam menentukan kelayakan anggota untuk menerima kredit membutuhkan waktu yang lama.

Pada penelitian ini, dibuatlah sistem pendukung keputusan untuk penentuan penerima kredit yang layak menggunakan metode SMART (SIMPLE MULTI ATTRIBUTE RATING TECHNIQUE). Proses metode SMART ini dilakukan untuk menentukan kriteria, bobot kriteria dan alternatif untuk melakukan pengolahan data dan perangkingan.

Hasil pengujian dari penerapan metode dalam sistem dan pengujian manual mempunyai hasil ranking perhitungan yang sama. Dan menyatakan dari pengujian fungsional sistem tersebut berjalan dengan cukup baik dan diharapkan dapat membantu menentukan penerima kredit koperasi yang layak.
\end{abstract}

Kata kunci : Sistem Pendukung Keputusan, Kredit, SMART, Koperasi

\section{PENDAHULUAN}

\subsection{Latar Belakang}

Koperasi adalah badan usaha yang beranggotakan perseorangan atau badan hukum koperasi yang melandaskan kegiatannya berdasarkan prinsip koperasi sekaligus sebagai gerakan ekonomi rakyat yang berdasarkan asas kekeluargaan. Salah satu kegiatan utama koperasi adalah menyediakan jasa penyimpanan dan pinjaman dana kepada anggota koperasi dengan tujuan memajukan kesejahteraan anggota khususnya pada masyarakat pada umumnya. Jenis kredit yang digunakan adalah jenis kredit menurut waktu yang pengembaliannya memerlukan jangka waktu pendek, menengah dan panjang. Didalam jangka waktu tersebut koperasi juga sering menghadapi resiko. Misalnya koperasi tidak menerima pembayaran dimuka ataupun sering terjadinya penunggakan atau keterlambatan dalam pembayaran dikarenakan berbagai alasan nasabah. Oleh karena itu, koperasi menentukan kebijakan dalam pemberian kredit antara lain menetapkan standar untuk menerima atau menolak resiko tersebut, yaitu dengan menentukan siapa yang berhak menerima kredit yang telah memenuhi standar yang ditetapkan koperasi.

Dalam hal penentuan kredit di Koperasi, proses penyeleksian kriteria dalam menentukan kelayakan anggota untuk menerima kredit membutuhkan waktu yang lama. Penyebabnya adalah proses perhitungan untuk tiap kriteria dikerjakan secara manual dengan cara sistem pencatatan untuk menentukan yang berhak sesuai kriteria-kriteria yang sudah ditentukan.
Berdasarkan latar belakang yang terjadi, bahwa Koperasi pada proses penyeleksian kriteria dalam menentukan kelayakan anggota untuk menerima kredit masih belum akurat. Oleh karena itu penulis bermaksud membuat aplikasi sistem perndukung keputusan menggunakan metode simple multi attribute rating technique pada Koperasi karena diperlukan metode yang mampu mendukung pengambilan keputusan dengan lebih cepat, tepat dan akurat. Dalam penelitian ini, metode yang digunakan adalah metode SMART. Metode SMART dirasa bisa membantu akuntan atau pemutus kredit untuk menentukan siapa yang berhak menerima kredit.

\subsection{Rumusan Masalah}

Berdasarkan permasalahan yang terindetifikasi diatas, maka dapat dirumuskan beberapa rumusan masalah yaitu :

1. Bagaimana merancang sistem pendukung keputusan penerima kredit koperasi berbasis web.

2. Bagaimana mengaplikasikan metode Simple Multi Attribute Rating Technique (SMART) pada sistem

\subsection{Tujuan}

Dari masalah - masalah yang telah dirumuskan, maka terdapat beberapa tujuan dari Skripsi ini, yaitu

1. Membuat aplikasi sistem pendukung keputusan berbasis web untuk menentukan penerima kredit pada Koperasi. 
2. Mengimplementasikan metode simple multi attribute rating technique untuk menentukan penerima kredit pada Koperasi.

\subsection{Batasan Masalah}

Agar permasalahan yang dimaksud tidak meluas, lebih terarah dan mudah dipahami maka diperlukan suatu batasan masalah dalam penelitian ini. Adapun batasan permasalahan pada penelitian ini, yaitu :

1. Sistem Pendukung Keputusan yang dibuat merupakan panduan dan alat bantu untuk menentukan calon penerima kredit, sedangkan keputusan akhir tetap berada pada pihak koperasi.

2. Data yang digunakan pada pengembangan ini adalah data pengajuan kredit unit simpan pinjam pada Koperasi Unit Desa Karangploso.

3. Kriteria yang digunakan dalam pendukung keputusan terdiri dari pinjaman, berkaitan dengan besaran pinjaman, angsuran, berkaitan dengan jangka waktu kredit, jaminan, berkaitan dengan harga jual jaminan, status, berkaitan dengan status peminjaman sebelumnya(jika ada).

4. Metode yang digunakan pada penelitian ini adalah Simple Multi Attribute Rating Technique.

5. Target pengguna hanya ditujukan untuk Admininstator unit simpan pinjam dan pemilik Koperasi.

6. Bahasa pemograman yang yang digunakan dalam proses pembuatan yaitu PHP dan JavaScript.

7. Platform yang digunakan pada penelitian ini adalah berbasis web dan basis data MySql.

\section{TINJAUAN PUSTAKA}

\subsection{Penelitian Terdahulu}

Sebelumnya, telah ada penelitian Mukhammad Farid Pradana yang berjudul "Sistem Pendukung Keputusan Penentuan Pemberian Beasiswa Kepada Siswa Yang Berprestasi dan Yang Kurang Mampu Menggunakan Metode Topsis", mengatakan bahwa banyak siswa beprestasi yang sulit untuk melajutkan sekolah karena beban biaya. Oleh sebab tersebut, maka dibuatlah sebuah sistem pendukung keputusan untuk menentukan pemberian beasiswa dengan menggunakan metode Technique For Order Preference by Similarity to Ideal Solution (TOPSIS). Kriteria yang digunakan dalam penelitian tersebut adalah nilai akademik siswa, kehadiran siswa, nilai ekstrakurikuler, rangking siswa, penghasilan orang tua siswa, pekerjaan orang tua siswa. Kemudian dari perhitungan metode TOPSIS didapatkan nilai prefensi yang akan digunakan untuk menentukan rangking yang digunakan untuk menentukan besiswa, serta menampilkan daftar siswa yang cocok untuk mendapatkan beasiswa, yang pada penelitian ini menampilkan 5 contoh data. [1]

Menurut Febry San Pratama, dkk pada penelitiannya yang berjudul "Sistem Pendukung Keputusan Penerimaan Siswa Baru Menggunakan Metode SAW (Studi Kasus: Smk Ipiems Surabaya)", menjelaskan bahwa banyaknya lulusan SMP yang meneruskan ke jenjang SMA/K ini tidak berbanding lurus dengan kuota bangku yang tersedia di SMA/K yang dituju. Maka digunakanlah sistem pendukung keputusan penerimaan siswa baru menggunakan metode Simple Additive Weighting, untuk memudahkan dalam menyeleksi siswa-siswi pendaftar yang memang berkompeten untuk memenuhi kuota di SMK IPIEMS Surabaya. Dari hasil penelitian tersebut, hasil perhitungan denan metode SAW di tampilkan dalam bentuk tabel untuk mengetahui siapa pendaftar dengan nilai tertinggi, dan juga grafik laporan kejuruan. [2]

Pada tahun 2016, Bayu Rianto, pada penelitiannya yang berjudul "Sistem Pendukung Keputusan Penerimaan Karyawan Menggunakan Metode Analytical Hierarchy Proses (AHP) Studi Kasus : RB. Nilam Sari Tembilahan, mengembangkan sistem pendukung keputusan (SPK) dengan memamfaatkan metode analytical hierarchy process (AHP) sebagai proses dalam seleksi penerimaan karyawan. Menggunakan 4 kriteria berupa pendidikan, performance, kemampuan berkomunikasi, dan motivasi dan antusiasme. Setelah menghitung 3 contoh data menggunakan metode AHP, didapatkan karyawan yang akan diterima, yaitu karyawan A dengan nilai(proritas global) 0.507. [3]

Ditahun 2018 penelitian yang dilakukan Wardani dan Saf menerapkan metode SMART pada sistem pendukung keputusan pemilihan kegiatan ektrakurikuler pada siswa SMA. Dengan banyaknya siswa SMA yang bingung ingin mengikuti ekstrakurikuler di sekolah. Pada penelitian ini memiliki 4 kriteria yaitu minat, bakat, waktu latihan, prestasi. [4]

Hatta dan kawan kawan dalam penelitian berjudul " Pemilihan Pemain Terbaik Futsal dengan Metode Simple Multi Attribute Rating Technique “ yaitu pemilihan pemain terbaik pada turnamen futsal di Kota Samarinda. Dengan banyaknya pemain pada turnamen tersebut panitia dapat kesulitan dalam memilih pemain terbaik. Pada penelitian ini bobot metode SMART menggunakan 4 kriteria yaitu diantaranya adalah : kontribusi, pelanggaran, sikap, dan panutan. [5].

\subsection{Koperasi}

Berdasarkan Undang-undang (UU) Nomor 25 Tahun 1992 tentang Perkoperasian, pada Pasal 1 dijelaskan, koperasi adalah badan usaha yang beranggotakan orang-seorang atau badan hukum koperasi dengan melandaskan kegiatannya berdasar prinsip koperasi, sekaligus sebagai gerakan ekonomi 
rakyat atas asas kekeluargaan. Sedangkan perkoperasian adalah segala sesuatu yang menyangkut kehidupan koperasi. [6]

\subsection{Metode SMART}

Metode SMART merupakan metode pengambilan keputusan multi kriteria yang dikembangkan oleh Edward pada tahun 1977. SMART merupakan teknik pengambilan keputusan multi kriteria ini didasarkan pada teori bahwa setiap alternatif terdiri dari sejumlah kriteria yang memiliki nilai-nilai dan setiap kriteria memiliki bobot yang menggambarkan seberapa penting ia dibandingkan dengan kriteria lain. Pembobotan ini digunakan untuk menilai setiap alternatif agar diperoleh alternatif terbaik. SMART menggunakan linear additive model untuk meramal nilai setiap alternatif. SMART merupakan metode pengambilan keputusan yang fleksibel. SMART lebih banyak digunakan karena kesederhanaanya dalam merespon kebutuhan pembuat keputusan dan caranya menganalisa respon. Analisa yang terlibat adalah transparan sehingga metode ini memberikan pemahaman masalah yang tinggi dan dapat diterima oleh pembuat keputusan. Adapun langkahnya sebagai berikut : [7]

Pertama yaitu menentukan menentukan kriteria yang digunakan dalam menyelesaikan masalah pengambilan keputusan. Untuk menentukan kriteriakriteria apa saja yang digunakan dalam sistem pengambilan keputusan ini diperlukan data-data dari pengambil keputusan atau pihak yang berwenang/kompeten terhadap masalah yang akan diselesaikan..

Langkah kedua yaitu menentukan alternatif yang akan digunakan untuk perhitungan.

Langkah ketiga yaitu penentuan bobot kriteria yang dimana di beri interval 1-100 untuk tiap-tiap kriteria dengan prioritas terpenting.

Langkah keempat yaitu melakukan normalisasi bobot kriteria yaitu menggunakan persamaan :

Dimana

$$
w i=\frac{w^{\prime i}}{\sum_{j=1}^{m} w j}
$$

- $\mathrm{Wi}=$ bobot kriteria ternormalisasi untuk kriteria ke-i

- $\mathrm{W}^{\prime} \mathrm{i}=$ bobot kriteria ke-i

- $\mathrm{Wj}=$ bobot kriteria ke-j

- $\mathrm{J}=1,2,3, \ldots \ldots ., \mathrm{m}$ jumlah kriteria

Langkah kelima yaitu memberikan nilai kriteria untuk setiap alternatif, nilai kriteria untuk setiap alternatif ini dapat berbentuk data kuantitatif (angka) ataupun berbentuk data kualitatif, misalkan nilai untuk kriteria harga sudah dapat dipastikan berbentuk kuantitatif sedangkan nilai untuk kriteria fasilitas bisa jadi berbentuk kualitatif (sangat lengkap, lengkap, kurang lengkap). Apabila nilai kriteria berbentuk kualitatif maka kita perlu mengubah ke data kuantitatif dengan membuat parameter nilai kriteria, misalkan sangat lengkap artinya 3, lengkap artinya 2 dan tidak lengkap artinya 1.

Langkah keenam yaitu Menentukan nilai utility dengan mengkonversikan nilai kriteria pada masingmasing kriteria menjadi nilai kriteria data baku. Nilai utility ini tergantung pada sifat kriteria itu sendiri.

Kriteria Biaya(cost kriteria). Kriteria yang bersifat

"lebih diinginkan nilai yang lebih kecil":

$$
\text { ui(ai) }=\frac{\text { Cmax }- \text { Cout }}{\text { Cmax }- \text { Cmin }}
$$

Kriteria Keuntungan(benefit kriteria). Kriteria yang bersifat "lebih diinginkan nilai yang lebih besar":

$$
\text { ui(ai) }=\frac{\text { Cout }- \text { Cmin }}{\text { Cmax }- \text { Cmin }}
$$

Dimana

- Ui(ai) adalah Bobot kriteria baris i kolom i.

- Cout adalah kriteria ke-i.

- Cmin adalah nilai minimal kriteria

- Cmax adalah nilai maksimal kriteria

Langkah keenam yaitu melakukan hitung akhir dengan cara :

$$
\mathrm{u}(\mathrm{ai})=\sum_{\mathrm{j}=1}^{\mathrm{m}} \mathrm{wj} * \mathrm{uj}(\mathrm{ai})
$$

\section{Dimana}

- U(ai) adalah nilai total untuk alternatif ke-i

- Wj adalah nilai bobot kriteria ke-j yang sudah ternormalisasi

- Uj(ai) adalah nilai utility kriteria ke-j untuk alternatif ke-i

\section{METODE PENELITIAN}

\subsection{Desain Arsitektur Sistem}

Desain arsitektur sistem pada rancangan sistem terdiri dari input, proses, output seperti pada gambar berikut :

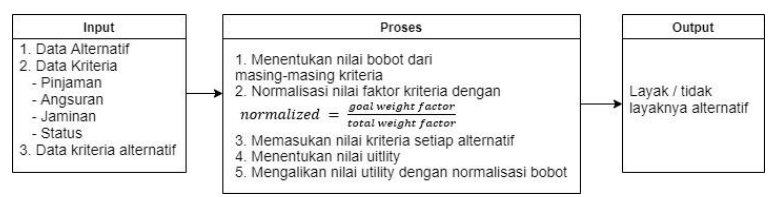

Gambar 1 Desain Arsitektur Sistem

Desain arsitektur sistem tabel 1 menunjukkan bahwa data masukan digunakan untuk melakukan perhitungan. Inputan berupa data anggota koperasi dengan kriteria berupa pinjaman, angsuran, jaminan, status. Data yang telah diinputkan akan diproses dengan Metode Smart seperti pada Tabel proses. Hasil perhitungan yang diperoleh merupakan output kelayakan alternatif. 


\subsection{Flowchart Metode SMART}

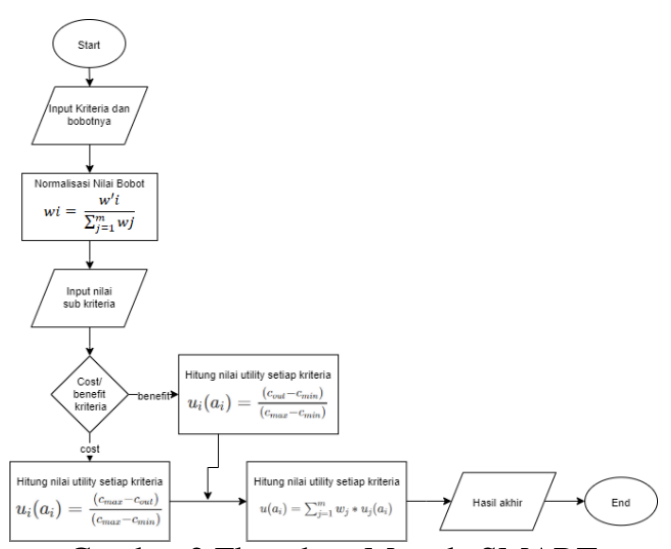

Gambar 2 Flowchart Metode SMART berikut:

Penejelasan dari flowchart SMART sebagai

Pertama menentukan kriteria yang akan digunakan dalam perhitungan dan memaasukan bobotnya.

Kedua yaitu menormalisasikan nilai bobot kriteria dengan menggunakan persamaan $(2,1)$.

Ketiga yaitu memasukan nilai sub kriteria dari kriteria.

Keempat yaitu menghitung nilai utility untuk setiap kriteria menggunakan persamaan $(2,2)$ atau persamaan $(2,3)$.

Kelima yaitu melakukan perhitungan akhir menggunakan persamaan $(2,4)$.

Keenam yaitu output hasil keputusan kelayakan suatu alternatif.

\subsection{Flowchart Sistem}

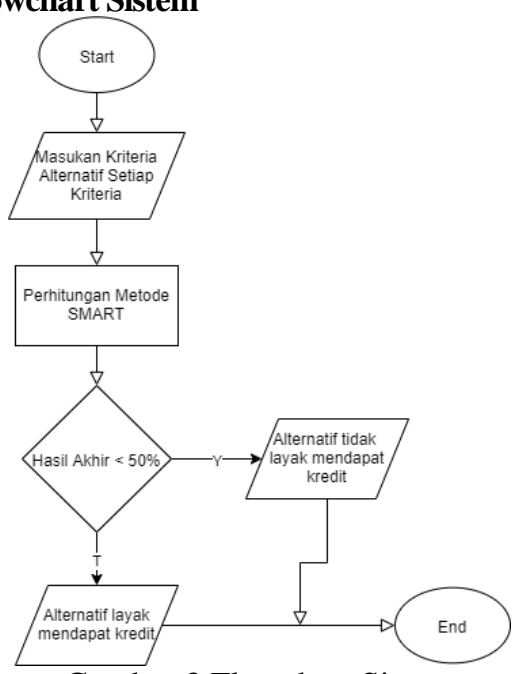

Gambar 3 Flowchart Sistem

Pada flowchart sistem di atas di awali dengan memasukan nilai kriteria alternatif. Pada kasus ini, data yang dimasukan adalah pinjaman, jaminan, status, dan angsuran. Kemudian program akan menghitung hasil yang telah dimasukan. Setelah hasil didapatkan, jika hasil diatas 50\% maka hasil output nya adalah alternatif yang dimasukan mendapatkan hasil layak untuk mendapatkan kredit, sementara untuk hasil diabawah $50 \%$ maka output yang dihasilkan adalah alternatif tidak layak untuk mendapatkan kredit.

\subsection{Struktur Menu Sistem}

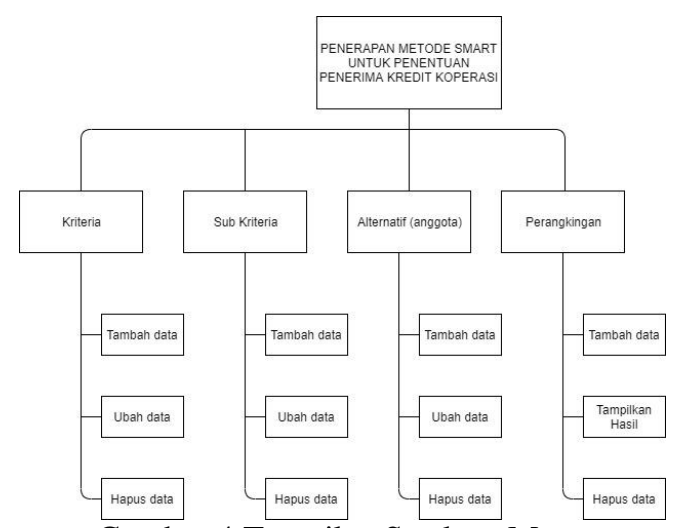

Gambar 4 Tampilan Struktur Menu

Pada struktur menu terdapat button kriteria digunakan untuk menuju form data kriteria, button sub kriteria digunakan untuk menuju form data sub kriteria, button alternatif digunakan untuk menuju form data alternatif, button perangkingan digunakan untuk menuju form data perangkingan. Form data kriteria, sub kriteria, alternatif, dan perangkingan digunakan untuk menambah, mengubah dan menghapus data yang akan ditampilkan pada halaman website. Dan juga ada button logout untuk admin yang ingin keluar dari menu admin

\subsection{Perhitungan Metode SMART}

Data training yang digunakan pada kasus ini berjumlah 10 data training.

Langkah 1. Menentukan Kriteria dan bobot kriteria. Dapat dilihat pada Tabel 1.

Tabel 1. Data kriteria

\begin{tabular}{|l|l|l|l|}
\hline No & $\begin{array}{l}\text { Nama } \\
\text { Kriteria }\end{array}$ & Bobot Kriteria & Tipe \\
\hline 1 & Pinjaman & 20 & Min \\
\hline 2 & Angsuran & 10 & Min \\
\hline 3 & Jaminan & 20 & Max \\
\hline 4 & Status & 70 & Max \\
\hline
\end{tabular}

Langkah 2. Melakukan Normalisai pada tiap bobot kriteria yang dapat dilihat pada tabel 2

Tabel 2. Tabel Hasil Normalisasi Bobot

\begin{tabular}{|l|l|l|l|}
\hline No & Nama Kriteria & $\begin{array}{l}\text { Bobot } \\
\text { Kriteria }\end{array}$ & Normaliasasi \\
\hline 1 & Pinjaman & 20 & 0.166666667 \\
\hline 2 & Angsuran & 10 & 0.083333333 \\
\hline 3 & Jaminan & 20 & 0.166666667 \\
4 & Status & 70 & 0.583333333 \\
\hline
\end{tabular}


Langkah 3. Menentukan alternatif yang merupakan nama dari siswa, dapat di lihat pada tabel 3 .

Tabel 3. Tabel Alternatif

\begin{tabular}{|l|l|}
\hline No & Nama Alternatif \\
\hline 1 & Lastin \\
\hline 2 & Sujoko/Saturi \\
\hline 3 & Hasyim \\
\hline 4 & Suwito \\
\hline 5 & Intan Ratnasari \\
\hline 6 & Kanifah \\
\hline 7 & H. Samsul \\
\hline 8 & Daroji \\
\hline 9 & Suparto \\
\hline 10 & Agus Purnomo \\
\hline
\end{tabular}

Langkah 4. Memasukkan nilai untuk tiap alternatif yang dapat di lihat pada tabel 4

Tabel 4. Nilai untuk tiap alternatif

\begin{tabular}{|c|c|c|c|c|}
\hline Nama & Pinjaman & $\begin{array}{l}\text { Angs } \\
\text { uran }\end{array}$ & $\begin{array}{c}\text { Jamina } \\
\mathbf{n}\end{array}$ & Status \\
\hline Lastin & Rp1,000,000 & 12 & $\begin{array}{l}\text { BPKB } \\
\text { Motor }\end{array}$ & Lancar \\
\hline $\begin{array}{l}\text { Sujoko/Sa } \\
\text { turi }\end{array}$ & Rp5,000,000 & 10 & $\begin{array}{l}\text { BPKB } \\
\text { Motor }\end{array}$ & $\begin{array}{c}\text { Belum } \\
\text { Ada }\end{array}$ \\
\hline Hasyim & Rp1,200,000 & 6 & $\begin{array}{l}\text { BPKB } \\
\text { Motor }\end{array}$ & Lancar \\
\hline Suwito & Rp8,000,000 & 4 & $\begin{array}{l}\text { BPKB } \\
\text { Mobil }\end{array}$ & Lancar \\
\hline $\begin{array}{l}\text { Intan } \\
\text { Ratnasari }\end{array}$ & Rp4,000,000 & 10 & $\begin{array}{l}\text { BPKB } \\
\text { Motor }\end{array}$ & $\begin{array}{c}\text { Tidak } \\
\text { Lancar }\end{array}$ \\
\hline Kanifah & Rp10,000,000 & 3 & $\begin{array}{l}\text { BPKB } \\
\text { Motor }\end{array}$ & Lancar \\
\hline H. Samsul & Rp6,000,000 & 6 & $\begin{array}{l}\text { BPKB } \\
\text { Motor }\end{array}$ & $\begin{array}{l}\text { Kurang } \\
\text { Lancar }\end{array}$ \\
\hline Daroji & $\mathrm{Rp} 3,000,000$ & 6 & $\begin{array}{l}\text { BPKB } \\
\text { Motor }\end{array}$ & $\begin{array}{c}\text { Belum } \\
\text { Ada }\end{array}$ \\
\hline Suparto & Rp9,000,000 & 6 & $\begin{array}{c}\text { SK } \\
\text { Kios }\end{array}$ & Lancar \\
\hline $\begin{array}{l}\text { Agus } \\
\text { Purnomo }\end{array}$ & Rp5,000,000 & 10 & $\begin{array}{l}\text { BPKB } \\
\text { Motor }\end{array}$ & Lancar \\
\hline
\end{tabular}

Nilai kriteria

Kriteria Jenis Normalisasi

Status Lancar 5

Kurang Lancar 3

Tidak Lancar 1

Belum Ada 4

Jaminan BPKB Motor 3

BPKB Mobil 5

SK Kios 4

Melakukan pencarian nilai utility dengan cara jika tipe kriteria adalah $\min ($ cost criteria) maka dihitung berdasarkan persamaan $(2,2)$

Sedangkan jika tipe kriteria max (benefit criteria) maka menggunakan persamaan $(2,3)$. Hasil yang didapat bisa di lihat di tabel 5
Tabel 5 Nilai Utility

\begin{tabular}{|c|c|c|c|c|}
\hline Alternatif & Pinjaman & Angsuran & 芯 & 莒 \\
\hline Lastin & 1 & 0 & 0 & 1 \\
\hline Sujoko/Saturi & 0.555555556 & 0.222222222 & 0 & 0.75 \\
\hline Hasyim & 0.977777778 & 0.666666667 & 0 & 1 \\
\hline Suwito & 0.222222222 & 0.888888889 & 1 & 1 \\
\hline $\begin{array}{c}\text { Intan } \\
\text { Ratnasari }\end{array}$ & 0.666666667 & 0.222222222 & 0 & 0 \\
\hline Kanifah & 0 & 1 & 0 & 1 \\
\hline H. Samsul & 0.444444444 & 0.666666667 & 0 & 0.5 \\
\hline Daroji & 0.777777778 & 0.666666667 & 0 & 0.75 \\
\hline Suparto & 0.111111111 & 0.666666667 & 0.5 & 1 \\
\hline $\begin{array}{c}\text { Agus } \\
\text { Purnomo }\end{array}$ & 0.555555556 & 0.222222222 & 0 & 1 \\
\hline
\end{tabular}

Langkah 6 Menghitung hasil akhir dengan cara normalisasi bobot dikali dengan nilai utility tiap kriteria, hasil di lihat pada tabel 6.

Tabel 6 Tabel Hasil Akhir

\begin{tabular}{|l|l|l|}
\hline No & \multicolumn{1}{|c|}{$\begin{array}{c}\text { Nama } \\
\text { Alternatif }\end{array}$} & \multicolumn{1}{c|}{ Hasil } \\
\hline 1 & Lastin & 0.75 \\
\hline 2 & Sujoko/Saturi & 0.548611111 \\
\hline 3 & Hasyim & 0.801851852 \\
\hline 4 & Suwito & 0.86111111 \\
\hline 5 & $\begin{array}{l}\text { Intan } \\
\text { Ratnasari }\end{array}$ & 0.12962963 \\
\hline 6 & Kanifah & 0.666666667 \\
\hline 7 & H. Samsul & 0.421296296 \\
\hline 8 & Daroji & 0.622685185 \\
\hline 9 & Suparto & 0.740740741 \\
\hline 10 & $\begin{array}{l}\text { Agus } \\
\text { Purnomo }\end{array}$ & 0.694444444 \\
\hline
\end{tabular}

Langkah 7 Jika hasil akhir dibawah 0,5, maka alternatif tersebut tidak layak. Hasil kelayakan dapat di lihat pada tabel 7

Tabel 7 Tabel Kelayakan

\begin{tabular}{|l|l|l|}
\hline No & \multicolumn{1}{|c|}{$\begin{array}{c}\text { Nama } \\
\text { Alternatif }\end{array}$} & \multicolumn{1}{c|}{ Hasil } \\
\hline 1 & Lastin & Layak \\
\hline 2 & Sujoko/Saturi & Layak \\
\hline 3 & Hasyim & Layak \\
\hline 4 & Suwito & Layak \\
\hline 5 & $\begin{array}{l}\text { Intan } \\
\text { Ratnasari }\end{array}$ & Tidak Layak \\
\hline 6 & Kanifah & Layak \\
\hline 7 & H. Samsul & Tidak Layak \\
\hline 8 & Daroji & Layak \\
\hline 9 & Suparto & Layak \\
\hline 10 & $\begin{array}{l}\text { Agus } \\
\text { Purnomo }\end{array}$ & Layak \\
\hline
\end{tabular}




\section{HASIL DAN PEMBAHASAN}

4.1. Tampilan Halaman Login

Tampilan halaman login yang diakses oleh user/pengguna sehingga perlu melakukan memasukkan username dan password terlebih dahulu. Halaman ini menunjukan halaman utama pada website sistem pendukung keputusan penerima kredit koperasi Tampilannya seperti Gambar 5.

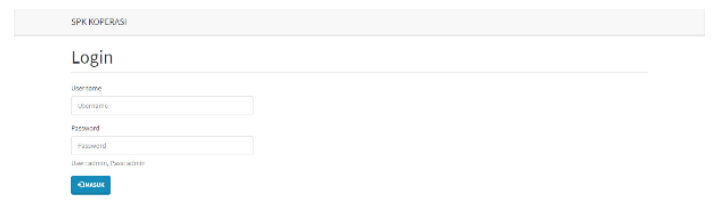

Gambar 5 Tampilan halaman login

\subsection{Tampilan Halaman Dashboard}

Tampilan halaman dasboard, menunjukkan informasi beberapa menu lain yaitu kriteria, sub kriteria, alternatif, perangkingan, operator. Tampilan halaman dashboard sepertu Gambar 6.

Selamat Datang, Admin

SPK Metode SMART

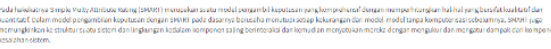

Gambar 6 Tampilan halaman dashboard

\subsection{Tampilan Halaman Kriteria}

Halaman data kriteria berisi nama kriteria, bobot kriteria, tombol tambah, edit dan hapus. Seperti Gambar 7.

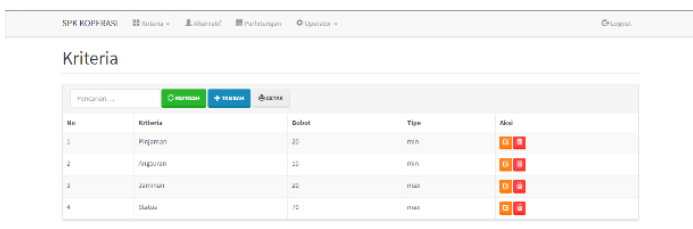

Gambar 7 Tampilan halaman kriteria

\subsection{Tampilan Halaman Tambah Kriteria}

Halaman kriteria tambah ada text box untuk menambahkan nama kriteria, bobot kriteria, serta tipe. Tampilan halaman tambah kriteria seperti pada gambar 8.

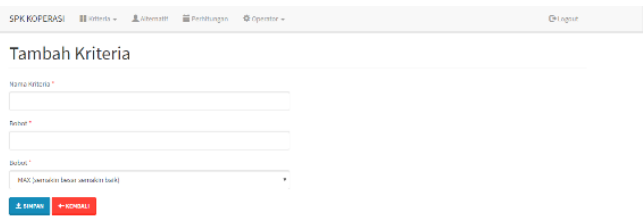

Gambar 8 Tampilan halaman tambah kriteria

\subsection{Tampilan Halaman Sub Kriteria}

Halaman sub kriteria terdapat terdapat beberapa list yang memunculkan nama kriteria dan nilai tiap sub kriteria seperti pada gambar 9.

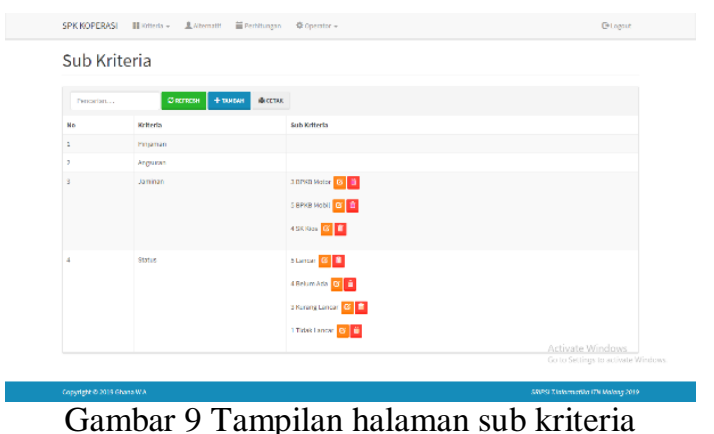

\subsection{Tampilan Halaman Tambah Sub Kriteria}

Pada halaman tambah sub kriteria, pengguna memasukan data nilai sub kriteria yang sesuai dengan kriteria. Tampilan halaman tambah sub kriteria seperti pada gambar 10 .

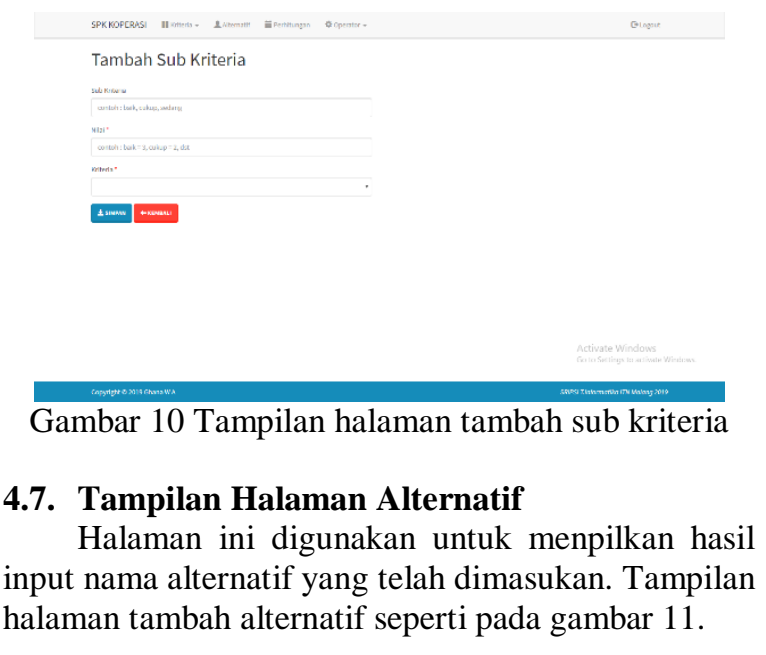




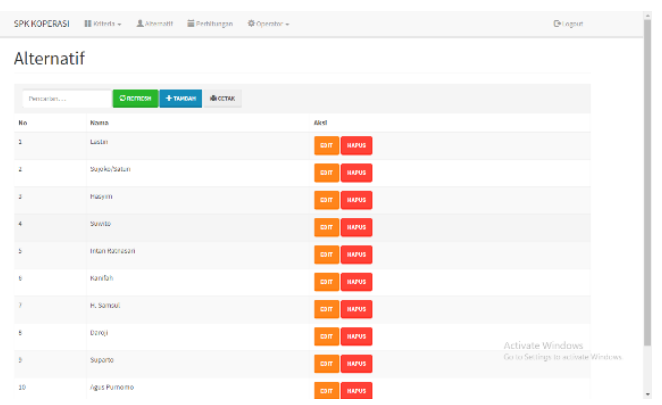

Gambar 11 Tampilan halaman alternatif

\subsection{Tampilan Halaman Tambah Alternatif}

Halaman tambah alternatif berisi form untuk memasukan nama kriteria baru. Tampilan halaman tambah alternatif seperti pada gambar 12 .
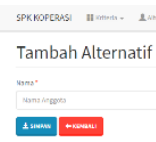

Gambar 12 Tampilan halaman tambah alternatif

\subsection{Tampilan Halaman Perhitungan}

Halaman ini merupakan halaman menpilkan nilai kriteria pada tiap alternatif dan terdapat tombol untuk eksekusi perangkingan dan tambah nilai alternatif. Tampilan halaman tambah alternatif seperti pada gambar 13 .

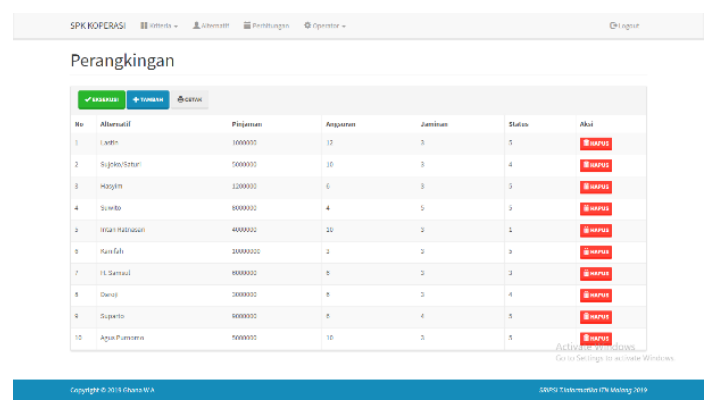

Gambar 13 Tampilan halaman perhitungan

\subsection{Tampilan Halaman Tambah Perhitungan}

Halaman ini berisi form untuk menambah nilai kriteria pada tiap alternatif. Tampilan halaman tambah alternatif seperti pada gambar 14 .

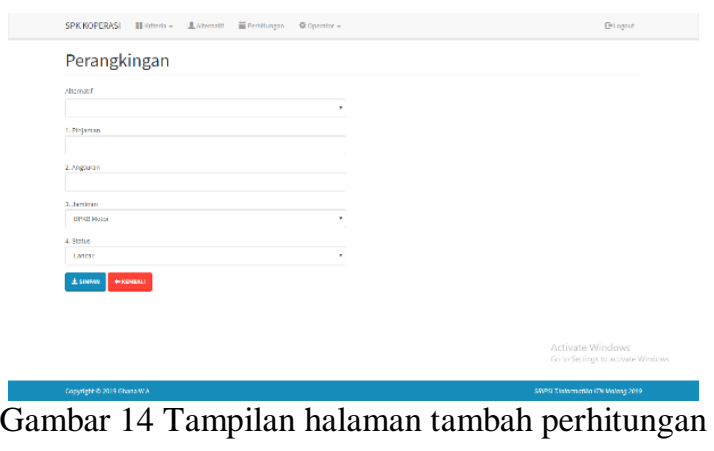

\subsection{Tampilan Halaman Eksekusi Perhitungan}

Halaman ini menampilkan hasil perhitungan dari nilai yang di masukkan pada halaman tambah perangkingan seperti ditunjukan pada gambar 15 .

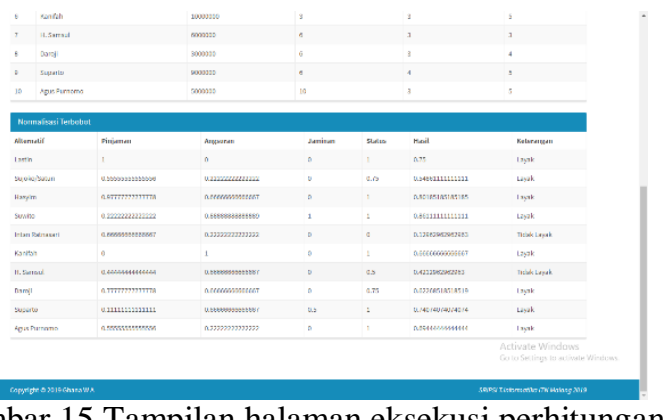

Gambar 15 Tampilan halaman eksekusi perhitungan

\subsection{Tampilan Halaman Operator}

Halaman ini berisi form untuk melihat data pengguna atau administrator. Tampilan halaman operato seperti pada gambar 16 .

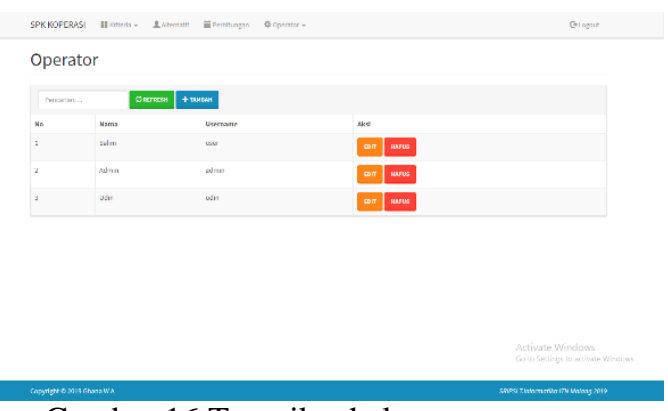

Gambar 16 Tampilan halaman operator

\subsection{Pengujian Browser}

Pada tahap pengujian browser menu website dilakukan dengan menggunakan 3 browser yaitu Google Chrome 78, Opera 65, dan Microsoft Edge. Pengujian ini dilakukan untuk mengetahui fungsional dari fitur-fitur pada aplikasi berbasis web. Hasil pengujian ditunjukkan pada tabel 8: 
Tabel 8. Tabel Pengujian Browser

\begin{tabular}{|l|c|c|c|}
\hline \multirow{2}{*}{\multicolumn{1}{c|}{ Fungsi }} & \multicolumn{3}{|c|}{ Broswer } \\
\cline { 2 - 4 } & $\begin{array}{c}\text { Google } \\
\text { Chrome }\end{array}$ & Opera & $\begin{array}{c}\text { Microsoft } \\
\text { Edge }\end{array}$ \\
\hline Halaman Login & $\checkmark$ & $\checkmark$ & $\checkmark$ \\
\hline Tombol Login & $\checkmark$ & $\checkmark$ & $\checkmark$ \\
\hline Halaman Dashboard & $\checkmark$ & $\checkmark$ & $\checkmark$ \\
\hline Halaman Kriteria & $\checkmark$ & $\checkmark$ & $\checkmark$ \\
\hline Tambah Kriteria & $\checkmark$ & $\checkmark$ & $\checkmark$ \\
\hline Hapus Kriteria & $\checkmark$ & $\checkmark$ & $\checkmark$ \\
\hline Halaman Edit Kriteria & $\checkmark$ & $\checkmark$ & $\checkmark$ \\
\hline Edit Kriteria & $\checkmark$ & $\checkmark$ & $\checkmark$ \\
\hline Halaman Sub Kriteria & $\checkmark$ & $\checkmark$ & $\checkmark$ \\
\hline Tambah Sub Kriteria & $\checkmark$ & $\checkmark$ & $\checkmark$ \\
\hline Halaman Edit Sub & $\checkmark$ & $\checkmark$ & $\checkmark$ \\
Kriteria & $\checkmark$ & $\checkmark$ & $\checkmark$ \\
\hline Edit Sub Kriteria & $\checkmark$ & $\checkmark$ & $\checkmark$ \\
\hline Hapus Sub Kriteria & $\checkmark$ & $\checkmark$ & $\checkmark$ \\
\hline Halaman Alternatif & $\checkmark$ & $\checkmark$ & $\checkmark$ \\
\hline Tambah Alternatif & $\checkmark$ & $\checkmark$ & $\checkmark$ \\
\hline Halaman Edit & $\checkmark l t e r n a t i f$ & $\checkmark$ & $\checkmark$ \\
\hline Edit Alternatif & $\checkmark$ & $\checkmark$ & $\checkmark$ \\
\hline Hapus Alternatif & $\checkmark$ & $\checkmark$ & $\checkmark$ \\
\hline Halaman Perhitungan & $\checkmark$ & $\checkmark$ & $\checkmark$ \\
\hline Tambah Perhitungan & $\checkmark$ & $\checkmark$ & \\
\hline Hapus Perhitungan & $\checkmark$ & $\checkmark$ & $\checkmark$ \\
\hline Halaman Eksekusi & $\checkmark$ & $\checkmark$ & $\checkmark$ \\
Perhitungan & & & \\
\hline Logout & & & \\
\hline Keterangan : & & & \\
\hline : Berhasil & & $\checkmark$ & $\checkmark$ \\
\hline X : Gagal & & & \\
\hline
\end{tabular}

\section{KESIMPULAN DAN SARAN}

\subsection{Kesimpulan}

Berdasarkan hasil dari perancangan dan implementasi dari sistem pendukung keputusan penentuan penerima kredit koperasi berbasis website maka penulis mendapat kesimpulan yaitu:

1. Berdasarkan hasil pengujian fungsional aplikasi sistem pendukung keputusan penentuan penerima kredit koperasi dapat berjalan dengan lancar.

2. Penerapan sistem pendukung keputusan menggunakan metode SMART berbasis website ini berjalan dengan baik pada 3 browser yaitu Google Chrome, Opera, dan Microsoft Edge.

3. Pada hasil perbandingan yang telah dilakukan, menggunakan 15 (lima belas) data yang telah diuji coba didapat hasil 93\% tingkat kecocokan antara hasil dari KUD Karangploso dan hasil dari program.

4. Dari penelitian dan analisa yang telah dilakukan ditemukan bahwa metode Simple Multi Attribute Rating Technique (SMART) kurang cocok diterapkan pada kasus penentuan keputusan penerima kredit koperasi.

\subsection{Saran}

Berdasarkan penelitian yang telah dilakukan maka penulis dapat memberikan saran-saran untuk pengembangan selanjutnya agar dalam aplikasi ini berjalan dengan lebih baik kedepannya, maka ada beberapa hal yang dapat dilakukan yaitu sebagai berikut:

1. Dari kesimpulan yang telah dihasilkan, pengembangan yang dapat dilakukan pada penelitian selanjutnya dengan cara melakukan komparasi dengan berbagai macam metode sistem pendukung keputusan yang sekiranya dapat menghasilkan hasil yang lebih tepat.

2. Melakukan pengembangan pada sistem dengan membuat program lebih optimal dan efektif sehingga halaman dan struktur menu dapat dibuat lebih praktis.

\section{DAFTAR PUSTAKA}

[1] Pradana Mukhamad Farid. SISTEM PENDUKUNG KEPUTUSAN PENENTUAN PEMBERIAN BEASISWA KEPADA SISWA YANG BERPRESTASI DAN YANG KURANG MAMPU MENGGUNAKAN METODE TOPSIS. Jurnal Mahasiswa Teknik Informatika, Vol. 3 No. 1, Maret 2019

[2] Febry San Pratama, Wiyli Yustanti. SISTEM PENDUKUNG KEPUTUSAN PENERIMAAN SISWA BARU MENGGUNAKAN METODE SAW (STUDI KASUS: SMK IPIEMS SURABAYA). Jurnal Manajemen Informatika. Volume 5 Nomor 2 Tahun 2016, 143 - 151

[3] Rianto, Bayu. Sistem Pendukung Keputusan Penerimaan Karyawan Menggunakan Metode Analytical Hierarchy Process (AHP) Studi Kasus : RB. Nilam Sari Tembilahan. Riau Journal Of Computer Science Vol.2 No.2 Tahun $2016: 29-38$.

[4] M.Tisa, D.K.W.Kartina, R.A.S. Maksum “ Implementasi Metode Smart pada sistem pendukung keputusan pemilihan kegiatan ekstrakurikuler untuk siswa SMA" Vol.13 No.1 Februari 2018

[5] R.H.Heliza, G. Budi, M. Khairina Dyna “" Pemilihan Pemain Terbaik Futsal Dengan Menggunakan Metode Simple Multi Attribute Rating Technique Studi Kasus : Turnamen di Samarinda"Jurnal Informatika Vol.11.No.1, Januari 2017

[6] Yuanita Intan, S.E. (2016). Pengertian Koperasi. https://www.studiobelajar.com/koperasi/.

[7] Pradita Stanislaus Yhanna " Sistem Pendukung Keputusan Pemilihan Kamera DSLR Menggunakan Metode Simple Multi Attribute Rating Technique ( SMART )"skripsi 2016 